\title{
ASSEMBLAGES OF NECROPHILOUS CARRION BEETLES (COL., SILPHIDAE) IN AGRICULTURALLY USED AREAS
}

\author{
KONIECZNA, K. ${ }^{*}$ - CZERNIAKOWSKI, Z. W. - WOLAŃSKI, P. \\ Department of Agroecology, Faculty of Biology and Agriculture, University of Rzeszów \\ Ćwiklińskiej 1, 35-601 Rzeszów, Poland \\ *Corresponding author \\ e-mail:vespillo1@gmail.com
}

(Received $19^{\text {th }}$ Oct 2018; accepted $2^{\text {nd }}$ Jan 2019)

\begin{abstract}
This study on Silphidae fauna was carried out at different sites forming part of an agricultural landscape. Catches were carried out in two selected habitats (Borek Stary and Widna Góra) in the Subcarpathian region (south-eastern Poland) during three growing seasons (2009-2010 and 2014) using Barber pitfall traps. It included potato, fodder beet and cereal crops (Widna Góra) as well as field margins (Borek Stary and Widna Góra). Four traps were placed at each of the sites studied then were emptied on average every two weeks. As a result of the observations, a total of 5491 beetles from 13 species were collected.
\end{abstract}

Keywords: Silphidae, Thanatophilus sinuatus, Nicrophorus vespillo, crop culture, field margins

\section{Introduction}

Most representatives of carrion beetles (Col., Silphidae) are necrophagous and/or predatory. Herbivorous species are a minority (Anderson and Peck, 1985; Sikes, 2008). Alongside ground beetles (Col., Carabidae) and rove beetles (Col., Staphylinidae), beetles from this family are an important component of epigeic entomofauna of agricultural landscape from the ecological point of view (Tischler, 1955). Necrophagous carrion beetles perform important ecological functions, which can be particularly seen in the agricultural aspect.

Biochemical transformations that accompany the decomposition of dead animals lead to an increased amount of mineral nutrients and humus in the soil and, as a further consequence, they affect soil fertility regeneration. Overall, they contribute to the cycling of elements in nature. In the aspect of agricultural crops that are at risk of outbreaks of many pests, among others gastropods (Gastropoda: Pulmonata: Stylommatophora), it is important to notice the positive biological role of carrion beetles. Silpha carinata is a predator of gastropods, both shelled snails and slugs (Dekeirsschieter et al., 2011). P. atrata atrata and A. laevigata laevigata, in which the characteristically elongated head facilitates shell penetration, exhibit a morphological adaptation for hunting shelled snails. Hunting strategies in these species have been described by Heymons and Lengerken (1932), Plate (1951), Linssen (1959), and Barronio (1974).

Agricultural progress and modern industrialization that aim to improve production in the food sector, given the growing human population, do not guarantee the sustainability of ecosystems. What is more, the loss of identity of ecosystems leads to the impoverishment of biodiversity (Wink et al., 2005). Anthropogenic pressure on agricultural landscape, which includes various agronomic practices, the use of fertilizers and crop protection chemicals as well as different plant and animal production systems, exerts an adverse impact on the diversity of zoocenoses occurring in agrarian landscape 
(Boone et al., 1999; Stoate et al., 2001; Porhajašová et al., 2015). Invertebrates, especially insects, are an animal group that is particularly sensitive to landscape changes. As a numerous and diverse component of different biocenoses, they perform important functions in ecosystems (Konieczna and Krupa, 2013), and a decline in their numbers may have a negative cascade effect (Coleman and Hendrix, 2000; Nichols et al., 2007).

The impact of agronomic practices on beneficial coleopterofauna has been identified quite well with regard to, among others, ground beetles (Col., Carabide) (Holland and Luff, 2000; Honěk and Jarošík, 2000; O'Rourke et al., 2008; Bukejs and Balalaikins, 2008; Bukejs, 2009; Eyre et al., 2012; Lemic et al., 2017; Schwerk and Dymitryszyn, 2017) and rove beetles (Col., Staphylinidae) (Bohac et al., 1999; Balog and Markó, 2006; Ghahari et al., 2009). As predatory entomophages, these both beetle families are frequently analyzed comprehensively (Andersen et al., 1983; Andresen, 1997; Frank and Reichhart, 2004; Tamutis et al., 2004). It should be indicated that the cited publications are only selected examples. However, as far as carrion beetles of arable fields are concerned, research is fragmentary. The studies conducted in the Czech Republic (Petruška, 1968; Novák, 1961, 1962; Kočárek and Benko, 1997; Kočárek, 1997; Růžička, 1994; Jakubec and Růžička, 2012; Stanovský et al., 2005), Austria (Juen et al., 2003), Luxembourg (Schlechter, 2008), Lithuania (Tamutis et al., 2007), and Poland (Kamińska, 1989; Konieczna et al., 2014) can be considered to be the most important publications presenting the occurrence of Silphidae in agriculturally used areas.

Apart from providing biological pest control, ground beetles (Arus et al., 2012; Renkema et al., 2014) are commonly considered to be bioindicators of environmental changes (Rainio and Niemelä, 2003; Agvin and Luff, 2010). Referring to the definition of McGeoch (1998), not only Carabidae, but also trophically different beetle families (Staphylinidae, Nitidulidae, Scarabaeidae, Scotylidae) can be regarded as indicator organisms (Beroiz et al., 2010). According to a study by dos Santos Fernandes et al. (2011), Silphidae can also be considered as potential biomarkers of environmental quality.

In analyzing the occurrence of beetles in agriculturally used areas, research on both areas that are subject to direct agricultural use (crop fields) and land that is excluded from such agricultural use (field boundary strips, field margins, and adjacent meadows) is worth undertaking. The need to conduct comparative studies was highlighted by Huruk (2006). Their results can be much more interesting and can allow us to infer on the impact of human activity on the natural environment. At the same time, it is worth noting that the negative impact of agricultural practices on organisms seems to be less noticeable in field margins (Marshall and Moonen, 2002). Taking this into account, the aim of this study was the following: (i) to identify the species composition of carrion beetles occurring in arable fields and field margins, (ii) to determine the dominance system of carrion beetles at such sites, and (iii) to compare the structure of assemblages of beetles caught.

\section{Materials and methods}

\section{Study sites}

This study on assemblages of necrophilous carrion beetles (Col., Silphidae) was conducted in south-eastern Poland in the years 2009, 2010, and 2014 (Fig. 1). Catching 
of entomofauna was carried out in Borek Stary (UTM EA73) and Widna Góra (UTM FA13/FA23). In Widna Góra, the study included the following crops: (i) a mixed cereal crop for animal feeding (at equal proportions of Avena sativa L., Hordeum vulgare L., and Triticum aestivum L.), (ii) fodder beet (Beta vulgaris L., semi-sugar type, cv. 'Zentaur Poly'), and (iii) potato (Solanum tuberosum L.), including the fields margins adjacent to these crops (iv, v, vi). In Borek Stary, the study was carried out on (vii) a field margin separating a mixed cereal crop for animal feeding (spring cereals: Avena sativa L. and Hordeum vulgare L.) and pastures (Fig. 2a-g).

\section{Methods for describing the study sites}

The field margins were characterized based on relevés made using the BraunBlanquet method. Due to the limited surface area of the field margins, the relevé area was $20 \mathrm{~m}^{2}$. To determine the cover-abundance of each of the identified species, the Braun-Blanquet seven-point scale was used (1964), in which a value of 5 corresponds to cover above $75 \%, 4-50-75 \%, 3-25-50 \%, 2-5-25 \%$, and $1-$ about $5 \%$. The symbol "+"denotes rare species (2-5 specimens), while $r$ - sporadic species (1 specimen) (Pawłowski, 1977; Wysocki and Sikorski, 2014). In the agriculturally used areas (the potato, fodder beet, and mixed cereal crops), due to the homogeneity of the crop stands, cover of layer $\mathrm{C}$ was accepted as $100 \%$ (100\% culture purity).

\section{Catching of carrion beetles}

This study was conducted over three growing seasons (2009-2010 and 2014). Beetles were captured using Barber pitfall traps, which were emptied at 14-day intervals. The pitfall traps were made of plastic containers with a diameter of $9 \mathrm{~cm}$, placed flush with the ground level, and filled with ethylene glycol solution to $1 / 3$ of their volume. Four traps were placed at each of the sites studied. They were monitored from the first 10 days of May to the third 10 days of October. Poultry slaughterhouse waste was used as bait. 11 harvests were carried out in 2009, whereas in 2010 and $2014-12$ in either of these years. The content of one trap from one harvest at one site was treated as one sample. Over the three-year study period, a total of 380 samples were taken for analysis. The captured entomological material was analyzed under laboratory conditions.

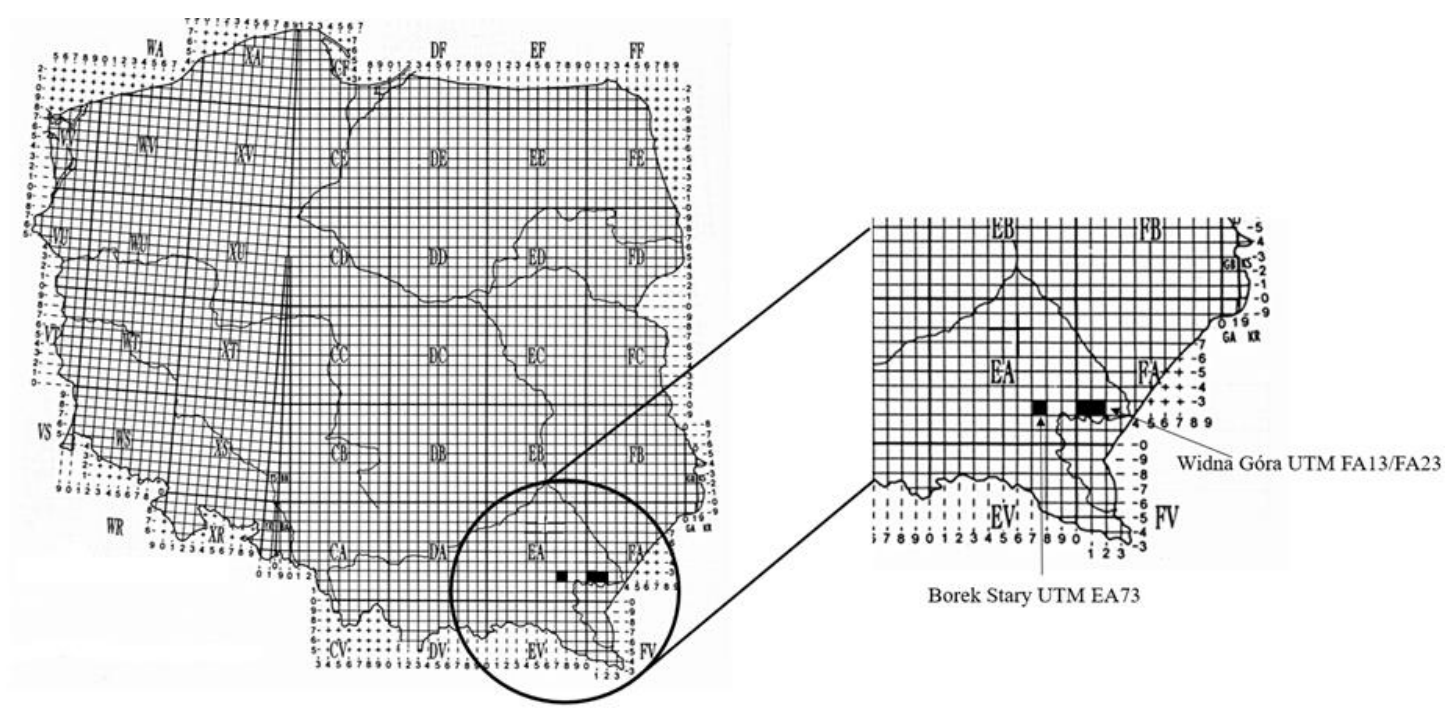

Figure 1. Location of the study area in south-eastern Poland (Subcarpathian Voivodeship) 

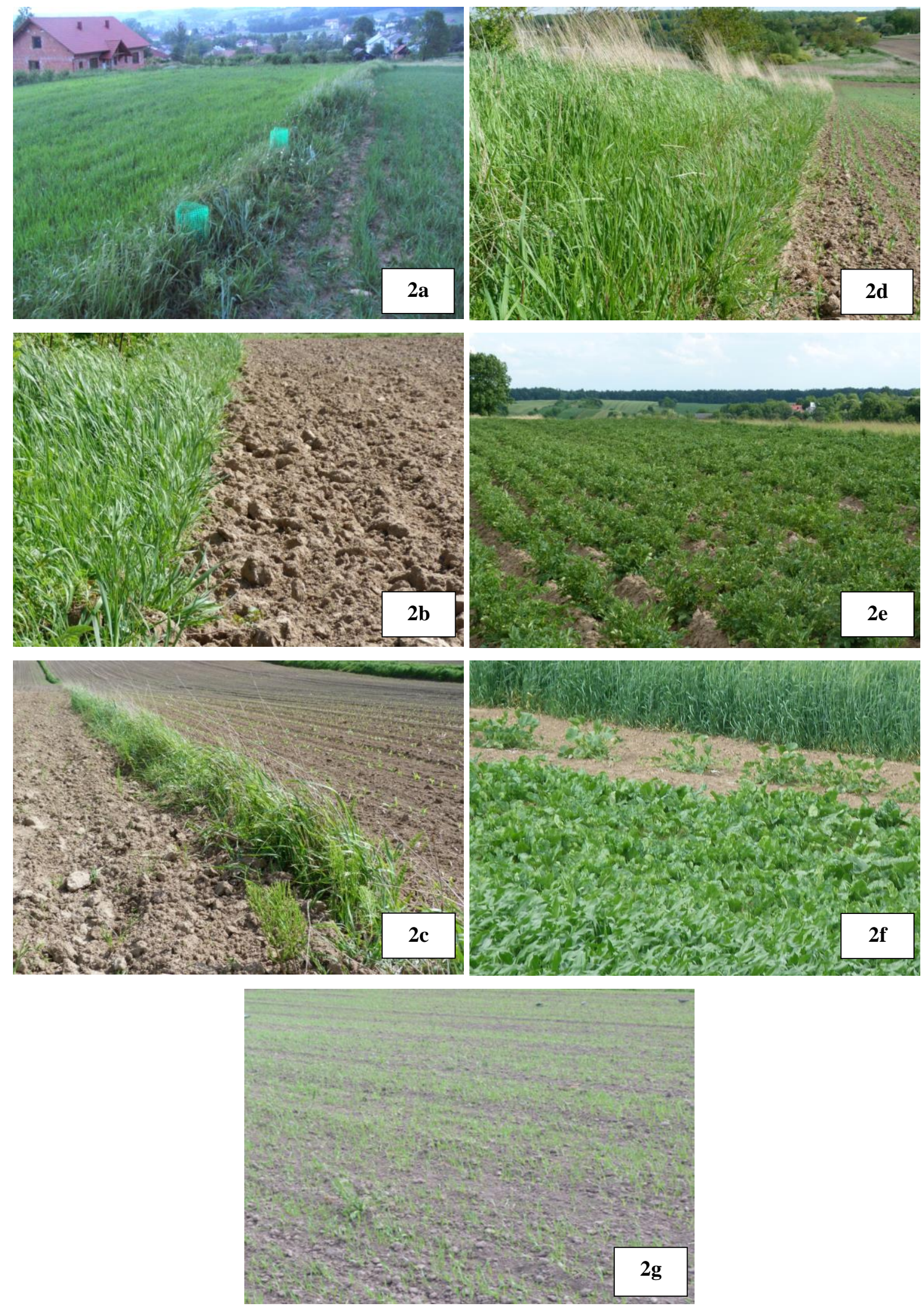

Figure 2. Study sites: $2 a$ - field margin between cereal crop and pasture; $2 b$-field margin between potato crop and meadow; $2 c$-field margin between fodder beet crop and cereal crop; $2 d$-field margin between cereal crop and meadow; $2 e$ - potato crop; $2 f$-fodder beet crop; $2 g$ cereal crop 


\section{Treatments}

Basic agronomic treatments, such as ploughing, harrowing, and fertilization, were done in the crop fields included in the entomological survey. In the potato crop field, the soil was fertilized with farmyard manure and a compound fertilizer, NPK(S) 6-20-30(7). The following foliar herbicides were applied: $70 \%$ metribuzin and quizalofop-Pethyl $50 \mathrm{~g} / \mathrm{l}$. To control the Colorado potato beetle (Leptinotarsa decemlineata Say), an insecticide containing zeta-cypermethrin was used. A concentrated boron fertilizer was additionally applied before row closure. The soil for the fodder beet crop was fertilized with a compound fertilizer, $\operatorname{NPK}(S)$ 6-20-30-(7). To improve the soil nutrient availability, a nitrogen fertilizer with boron was additionally applied. To control weeds, two herbicides were used: S-metolachlor $960 \mathrm{~g} / \mathrm{l}$ and $43.0 \%$ chloridazon. After fodder beet emergence, the following foliar fertilizers were applied: a nitrogen-magnesium concentrate and boron ethanolamine. In the mixed cereal crop, a foliar herbicide containing S-metolachlor $960 \mathrm{~g} / \mathrm{l}$ was used.

In the field margins separating the crop fields, the only agronomic treatment was single grass cutting after harvest of the crops in the adjacent fields.

\section{Nomenclature and statistical analyses}

Beetles were identified using the keys of Mroczkowski (1955) and Šustek (1981). The qualitative and quantitative characteristics of Silphidae caught were analyzed using zoocenological indices such as the dominance index (D), the Shannon-Wiener species diversity index $\left(\mathrm{H}^{\prime}\right)$, and the Pielou species evenness index $\left(\mathrm{J}^{\prime}\right)$ (Shannon and Weaver, 1949; Pielou, 1966; Górny and Grüm, 1981). To evaluate the significance of differences in the number of species and individuals of carrion beetles (Col., Silphidae) trapped at the individual sites, a Chi-squared test was used $\left(\chi^{2}\right)$. To determine similarities between the assemblages of beetles caught, the following was used: (i) cluster analysis using the Ward agglomeration method, in which the Euclidean distance was accepted as a measure of similarity, and (ii) faunistic similarity using the Sørensen formula (P) (Magurran, 2004). The level of significance (the maximum allowable probability of type I error) was set at $\alpha \leq 0.05$. The obtained results were statistically analyzed using Statistica v.12 and Excel 2007 software.

\section{Results}

\section{Results of investigation of the floral composition}

The results of the phytosociological analysis of the field margins are shown in Table 1 .

Generally, the number of plant species identified in the field margins was high, with the highest number in the field margin located next to the mixed cereal crop in Borek Stary. The percentage of plants in ground cover was there as much as $95 \%$, while $66 \%$ of the species can be described as characteristic of hay meadows. These were predominantly the following grasses with varying fodder value: Festuca rubra, Holcus lanatus, Agrostis capillaris, Dactylis glomerata, and Arrhenatherum elatius, among which the following dicotyledonous herbs were found, among others: Geranium pratense, Leontodon autumnalis, Plantago lanceolata, and Taraxacum officinale. The percentage of papilionaceous plants was low and they accounted for $11 \%$ of the total plant cover. 
Table 1. Floral composition of the field margins studied

\begin{tabular}{|c|c|c|c|c|}
\hline \multicolumn{5}{|c|}{ Study site } \\
\hline & Borek Stary & & Widna Góra & \\
\hline Cover & \begin{tabular}{|c|}
$\begin{array}{c}\text { Field margin in cereal } \\
\text { crop }\end{array}$ \\
\end{tabular} & \begin{tabular}{|c|}
$\begin{array}{c}\text { Field margin in potato } \\
\text { crop }\end{array}$ \\
\end{tabular} & $\begin{array}{c}\text { Field margin in } \\
\text { fodder beet crop }\end{array}$ & \begin{tabular}{|c|} 
Field margin in cereal \\
crop
\end{tabular} \\
\hline $\mathbf{A}$ & - & - & - & - \\
\hline B & - & - & - & - \\
\hline $\mathbf{C}$ & $\begin{array}{c}100 \% \\
\text { Festuca rubra } 4, \\
\text { Holcus lanatus } 3, \\
\text { Agrostis capillaris } 2, \\
\text { Dactylis glomerata 2, } \\
\text { Potentilla anserina } 2, \\
\text { Vicia sepium } 2, \\
\text { Arrhenatherum elatius } \\
1, \text { Equisetum arvense } 1, \\
\text { Bromus hordeaceus }+, \\
\text { Capsella bursa- } \\
\text { pastoris }+, \text { Cirsium } \\
\text { arvense }+, \text { Convolvulus } \\
\text { arvensis }+, \\
\text { Deschampsia } \\
\text { caespitosa }+, \\
\text { Epilobium hirsutum }+, \\
\text { Erigeron annuus }+, \\
\text { Festuca arundinacea }+, \\
\text { Geranium dissectum }+, \\
\text { Geranium pratense }+, \\
\text { Geum urbanum }+, \\
\text { Leontodon autumnalis } \\
+, \text { Luzula campestris }+, \\
\text { Plantago lanceolata }+, \\
\text { Poa pratensis }+, \\
\text { Potentilla erecta }+, \\
\text { Setaria viridis }+, \\
\text { Stellaria graminea }+, \\
\text { Taraxacum officinale } \\
+, \text { Trifolium dubium }+, \\
\text { Trifolium pratense }+, \\
\text { Trifolium repens }+, \\
\text { Urtica dioica }+, \text { Vicia } \\
\text { cracca }+, \text { Vicia } \\
\text { grandiflora }+, \text { Vicia } \\
\text { tetrasperma }+, \\
\text { Solidago gigantea } \mathrm{r} . \\
\end{array}$ & $\begin{array}{c}95 \% \\
\text { Arrhenatherum elatius } \\
\text { 4, Dactylis glomerata } \\
\text { 3, Achillea millefolium } \\
2, \text { Agrostis capillaris } 2, \\
\text { Elymus repens } 2, \\
\text { Glechoma hederacea 2, } \\
\text { Holcus lanatus } 2, \\
\text { Galinsoga parviflora } 1, \\
\text { Taraxacum officinale } 1, \\
\text { Aegopodium } \\
\text { podagraria }+, \text { Apera } \\
\text { spica-venti }+, \text { Artemisia } \\
\text { vulgaris }+, \\
\text { Calamagrostis epigejos } \\
+, \text { Cerastium } \\
\text { holosteoides }+, \\
\text { Convolvulus arvensis } \\
+, \text { Equisetum arvense } \\
+, \text { Erigeron annuus }+, \\
\text { Fallopia convolvulus }+, \\
\text { Festuca arundinacea }+, \\
\text { Galium mollugo }+, \\
\text { Geranium dissectum }+, \\
\text { Geum urbanum }+, \\
\text { Gnaphalium } \\
\text { uliginosum }+, \\
\text { Leontodon hispidus }+, \\
\text { Lolium perenne }+, \\
\text { Plantago major }+, \\
\text { Ranunculus repens }+, \\
\text { Setaria viridis }+, \\
\text { Solidago gigantea }+, \\
\text { Thlaspi arvense }+, \\
\text { Trifolium pratense }+, \\
\text { Urtica dioica }+, \text { Vicia } \\
\text { cracca }+. \\
\text {, }\end{array}$ & $\begin{array}{c}80 \% \\
\text { Elymus repens } 3, \\
\text { Artemisia vulgaris } \\
2, \text { Fallopia } \\
\text { convolvulus } 2, \\
\text { Holcus lanatus } 2, \\
\text { Chenopodium } \\
\text { polyspermum } 1, \\
\text { Agrostis capillaris } \\
+, \text { Arrhenatherum } \\
\text { elatius }+, \\
\text { Chenopodium } \\
\text { album }+, \text { Cirsium } \\
\text { arvense }+, \\
\text { Convolvulus } \\
\text { arvensis }+, \text { Dactylis } \\
\text { glomerata }+, \\
\text { Erigeron annuus }+, \\
\text { Festuca rubra }+, \\
\text { Galinsoga } \\
\text { parviflora }+, \\
\text { Geranium } \\
\text { dissectum }+, \\
\text { Gnaphalium } \\
\text { uliginosum }+, \\
\text { Lolium perenne }+, \\
\text { Phleum pratense }+, \\
\text { Polygonum } \\
\text { aviculare }+, \\
\text { Polygonum } \\
\text { persicaria }+, \\
\text { Setaria viridis }+, \\
\text { Stellaria media }+, \\
\text { Tanacetum vulgare } \\
+, \text { Brassica napus } \\
\text { var. napus } \mathrm{r} . \\
\text { ar }\end{array}$ & $\begin{array}{c}100 \% \\
\text { Calamagrostis epigejos } \\
4, \text { Elymus repens } 3, \\
\text { Urtica dioica } 3, \\
\text { Artemisia vulgaris } 2, \\
\text { Convolvulus arvensis } 2, \\
\text { Solidago gigantea } 2, \\
\text { Festuca arundinacea } 1, \\
\text { F. rubra } 1, \text { Geum } \\
\text { urbanum } 1, \text { Holcus } \\
\text { lanatus } 1, \text { Achillea } \\
\text { millefolium }+, \\
\text { Aegopodium } \\
\text { podagraria }+, \text { Agrostis } \\
\text { capillaris }+, \text { Anthriscus } \\
\text { sylvestris }+, \text { Armoracia } \\
\text { rusticana }+, \text { Cirsium } \\
\text { arvense }+, \text { Daucus } \\
\text { carota }+, \text { Epilobium } \\
\text { parviflorum }+, \\
\text { Erigeron annuus }+, \\
\text { Galeopsis tetrahit }+, \\
\text { Galinsoga parviflora }+, \\
\text { Glechoma hederacea }+, \\
\text { Hypochaeris radicata } \\
+, \text { Lamium album }+, \\
\text { Lysimachia } \\
\text { nummularia }+, \text { Phleum } \\
\text { pratense }+, \text { Plantago } \\
\text { lanceolata }+, \\
\text { Polygonum aviculare } \\
+, \text { Setaria glauca }+, \\
\text { Taraxacum officinale } \\
++\end{array}$ \\
\hline
\end{tabular}

A- tree layer, B- shrub layer, C- herb layer

The vegetation found in the field margin bordering the potato crop in Widna Góra also showed certain relationships with hay meadows. Arrhenatherum elatius and Dactylis glomerata were the dominant species there, whereas among dicotyledonous species the following grew most frequently: Achillea millefolium, Glechoma hederacea, and Taraxacum officinale. The percentage of segetal species in the ground cover of the studied patch was only $13 \%$. These were typical weeds accompanying root crops. 
The vegetation found in the field margins adjacent to the fodder beet and mixed cereal crops in Widna Góra was distinguished by a different floristic composition. There, segetal and ruderal plants were found to have a distinctly higher percentage, both in terms of the number of species and cover. Most segetal species grew in the field margin located in the vicinity of the fodder beet crop, and these were the following, among others: Elymus repens, Galinsoga parviflora, Chenopodium polyspermum, Ch. album, Fallopia convolvulus, Cirsium arvense, Polygonum persicaria, and $P$. aviculare. They accounted for as much as $62 \%$ of the ground cover of the studied patch. The percentage of plants typical of hay meadows was small and they were primarily represented by Holcus lanatus.

The vegetation found in the field margin next to the mixed cereal crop was characterized by the highest presence of ruderal plants. Their percentage in the total number of species was $27 \%$, while in the cover it was as much as $57 \%$. Attention should be paid to Solidago gigantea, a species considered to be invasive in Poland, which occurred in large numbers (Tokarska-Guzik et al., 2012; Otręba and Michalska-Hejduk, 2014) and which was accompanied by Calamagrostis epigejos, a species that grows in great numbers in set-aside meadows and fields (Barabasz-Krasny, 2011; Kryszak et al., 2006). Among ruderal species, the following occurred: Urtica dioica, Erigeron annuus, Geum urbanum, Anthriscus sylvestris, and Epilobium parviflorum, while as regards field weeds, the following grew most frequently: Elymus repens, Convolvulus arvensis, and Artemisia vulgaris. Plants typical of hay meadows were found in small numbers.

\section{Results of investigation of carrion beetles}

A total of 5491 beetle individuals belonging to 13 Silphidae species were collected, and the highest number of beetles was found in the field margin in Borek Stary (Table 2). Statistically significant differences in the number of individuals trapped were found ( $\mathrm{p}<0.05)$, but no differences were found in the number of species $(\mathrm{p}=0.8228)$. The subfamily Silphinae, with 4035 individuals and 7 species, was represented in greatest numbers. The sites where all identified species were found were the following: the field margin in Borek Stary, the field margin next to the potato crop, and the field margin adjacent to the mixed cereal crop in Widna Gora. At the same time, these were the sites that were characterized by the highest similarity $(\mathrm{P}=100.0 \%)$. It was also observed that, in faunistic terms, the field margins investigated showed a greater similarity to one another than in the case of the field margin - adjacent crop field system (Table 3).

T. sinuatus was the species that was found in all the sampling areas and which dominated the cover-abundance distribution (3229 individuals) (Fig. 3a). Another species that was found in large numbers at all the sites was the eurytopic species $N$. vespillo which, likewise $T$. sinuatus, belonged to the eudominant class (Table 3; Fig. $3 b$ ). Moreover, a third eudominant was found to be present in the field margin next to the potato crop and in the margin next to the mixed cereal crop. These species were $S$. obscura obscura and $O$. thoracicum, respectively. $N$. sepultor was a taxon that showed the lowest numbers (11 specimens). The lowest number of identified species was found in the fodder beet crop ( 8 species).

To evaluate the species diversity, the commonly applied indices were used (Table 2). Generally, these coefficients showed higher values for the field margins than for the crop fields adjacent to them. The Shannon-Weaver index exhibits higher values for the less numerous assemblages, but with a good structure. The highest value of this index 
$\left(\mathrm{H}^{\prime}=0.83\right)$ was recorded in the field margin bordering the mixed cereal crop. It was the site where the highest number of species was found (13), but at the same time an even distribution of the dominance class (Table 4) and the lowest number of individuals (628 beetles). At this site, the evenness of species distribution also showed the highest value $\left(\mathrm{J}^{\prime}=0.22\right)$.

Table 2. Species composition, abundance, and species diversity index of Silphidae caught in crop fields $(F)$ and field margins $(M)$

\begin{tabular}{c|c|c|c|c|c|c|c|c}
\hline \multirow{2}{*}{ Species } & \multicolumn{2}{|c|}{ Borek Stary } & \multicolumn{5}{c}{ Widna Góra } \\
\cline { 2 - 9 } & $\mathbf{2 0 0 9}$ & $\mathbf{2 0 1 0}$ & \multicolumn{2}{|c}{$\mathbf{2 0 1 4}$} \\
\cline { 2 - 8 } & \multicolumn{2}{|c|}{ Cereal } & \multicolumn{2}{|c}{ Potato } & Fodder beet & \multicolumn{2}{c}{ Cereal } \\
\cline { 2 - 9 } & M & M & F & M & F & M & F & M \\
\hline Oiceoptoma thoracicum L. & 60 & 37 & 1 & 5 & 6 & 10 & 18 & 67 \\
Phosphuga atrata atrata L. & 14 & 7 & 0 & 2 & 5 & 3 & 30 & 11 \\
Silpha carinata Hbst. & 2 & 1 & 5 & 2 & 0 & 1 & 19 & 23 \\
Silpha obscura obscura L. & 76 & 53 & 16 & 66 & 41 & 13 & 30 & 42 \\
Silpha tristis Ill. & 16 & 29 & 0 & 10 & 0 & 4 & 0 & 3 \\
Thanatophilus rugosus L. & 17 & 13 & 5 & 7 & 4 & 15 & 5 & 12 \\
Thanatophilus sinuatus F. & 977 & 685 & 355 & 129 & 302 & 262 & 310 & 209 \\
Nicrophorus humator Gleditsch & 10 & 15 & 0 & 2 & 0 & 2 & 21 & 10 \\
Nicrophorus interruptus Steph. & 5 & 3 & 0 & 2 & 6 & 1 & 31 & 21 \\
Nicrophorus investigator Zett. & 0 & 2 & 2 & 4 & 0 & 1 & 0 & 14 \\
Nicrophorus sepultor Charp. & 0 & 1 & 1 & 3 & 0 & 0 & 2 & 4 \\
Nicrophorus vespillo L. & 243 & 231 & 69 & 87 & 103 & 64 & 194 & 170 \\
Nicrophorus vespilloides Hbst. & 26 & 21 & 3 & 8 & 7 & 12 & 13 & 42 \\
\hline Total - number of specimens & 1446 & 1098 & 457 & 327 & 474 & 388 & 673 & 628 \\
Total - number of species & 11 & 13 & 9 & 13 & 8 & 12 & 11 & 13 \\
Shannon-Weaver index (H') & 0.59 & 0.54 & 0.34 & 0.70 & 0.47 & 0.50 & 0.68 & 0.83 \\
Pielou's evenness index (J') & 0.17 & 0.15 & 0.11 & 0.19 & 0.16 & 0.14 & 0.20 & 0.22 \\
\hline
\end{tabular}

Table 3. Similarity of Silphidae communities (\%) at the study sites

\begin{tabular}{|c|c|c|c|c|c|c|c|c|c|}
\hline \multirow{2}{*}{\multicolumn{3}{|c|}{ Study site }} & \multirow{3}{*}{\begin{tabular}{|c|} 
Borek Stary \\
Cereal \\
M \\
\end{tabular}} & \multicolumn{6}{|c|}{ Widna Góra } \\
\hline & & & & \multicolumn{2}{|c|}{ Potato } & \multicolumn{2}{|c|}{ Fodder beet } & \multicolumn{2}{|c|}{ Cereal } \\
\hline & & & & $\mathbf{F}$ & $\mathbf{M}$ & \multirow{2}{*}{$\frac{\mathbf{F}}{76.2}$} & \multirow{2}{*}{$\begin{array}{c}\mathbf{M} \\
96.0\end{array}$} & $\mathbf{F}$ & $\mathbf{M}$ \\
\hline Borek Stary & Cereal & $\mathbf{M}$ & - & 63.6 & 100.0 & & & 91.7 & 100.0 \\
\hline \multirow{6}{*}{ Widna Góra } & \multirow{2}{*}{ Potato } & $\mathbf{F}$ & 63.6 & - & 81.2 & 70.6 & 76.2 & 80.0 & 81.2 \\
\hline & & M & 100.0 & 81.2 & - & 76.2 & 96.0 & 91.7 & 100.0 \\
\hline & \multirow{2}{*}{$\begin{array}{c}\text { Fodder } \\
\text { beet }\end{array}$} & $\mathbf{F}$ & 76.2 & 70.6 & 76.2 & - & 70.0 & 84.2 & 76.2 \\
\hline & & M & 96.0 & 76.2 & 96.0 & 70.0 & - & 87.0 & 96.0 \\
\hline & \multirow{2}{*}{ Cereal } & $\mathbf{F}$ & 91.7 & 80.0 & 91.7 & 84.2 & 87.0 & - & 91.7 \\
\hline & & $\mathbf{M}$ & 100.0 & 81.2 & 100.0 & 76.2 & 96.0 & 91.7 & - \\
\hline
\end{tabular}

F- crop fields, $\mathrm{M}$ - field margins 
Table 4. Dominance of Silphidae caught in crop fields $(F)$ and field margins $(M)$

\begin{tabular}{|c|c|c|c|c|c|c|c|c|}
\hline \multirow{3}{*}{ Species } & \multirow{2}{*}{\multicolumn{2}{|c|}{$\begin{array}{c}\text { Borek Stary } \\
\text { Cereal }\end{array}$}} & \multicolumn{6}{|c|}{ Widna Góra } \\
\hline & & & \multicolumn{2}{|c|}{ Potato } & \multicolumn{2}{|c|}{ Fodder beet } & \multicolumn{2}{|c|}{ Cereal } \\
\hline & M & M & $\mathbf{F}$ & $\mathbf{M}$ & $\mathbf{F}$ & $\mathbf{M}$ & $\mathbf{F}$ & $\mathbf{M}$ \\
\hline Oiceoptoma thoracicum $\mathrm{L}$. & SD & SD & SR & $\mathrm{R}$ & $\mathrm{R}$ & SD & SD & ED \\
\hline Phosphuga atrata atrata $\mathrm{L}$. & SR & SR & - & SR & $\mathrm{R}$ & SR & SD & $\mathrm{R}$ \\
\hline Silpha carinata Hbst. & SR & SR & $\mathrm{R}$ & SR & - & SR & SD & $\mathrm{SD}$ \\
\hline Silpha obscura obscura L. & $\mathrm{D}$ & SD & SD & ED & $\mathrm{D}$ & SD & SD & $\mathrm{D}$ \\
\hline Silpha tristis Ill. & $\mathrm{R}$ & SD & - & SD & - & $\mathrm{R}$ & - & SR \\
\hline Thanatophilus rugosus $\mathrm{L}$. & $\mathrm{R}$ & $\mathrm{R}$ & $\mathrm{R}$ & SD & SR & SD & SR & $\mathrm{R}$ \\
\hline Thanatophilus sinuatus F. & ED & ED & ED & ED & ED & ED & ED & ED \\
\hline Nicrophorus humator Gleditsch & SR & $\mathrm{R}$ & - & SR & - & SR & SD & $\mathrm{R}$ \\
\hline Nicrophorus interruptus Steph. & SR & SR & - & SR & $\mathrm{R}$ & SR & SD & SD \\
\hline Nicrophorus investigator Zett. & - & SR & SR & $\mathrm{R}$ & - & SR & - & $\mathrm{SD}$ \\
\hline Nicrophorus sepultor Charp. & - & SR & SR & SR & - & - & SR & $\mathrm{SR}$ \\
\hline Nicrophorus vespillo L. & ED & ED & $\mathrm{ED}$ & ED & ED & ED & ED & $\mathrm{ED}$ \\
\hline Nicrophorus vespilloides Hbst. & $\mathrm{R}$ & $\mathrm{R}$ & SR & SD & $\mathrm{R}$ & SD & $\mathrm{R}$ & $\mathrm{D}$ \\
\hline
\end{tabular}

ED- eudominants, D- dominants, SD- subdominants, R- recedents, SR- subrecedents
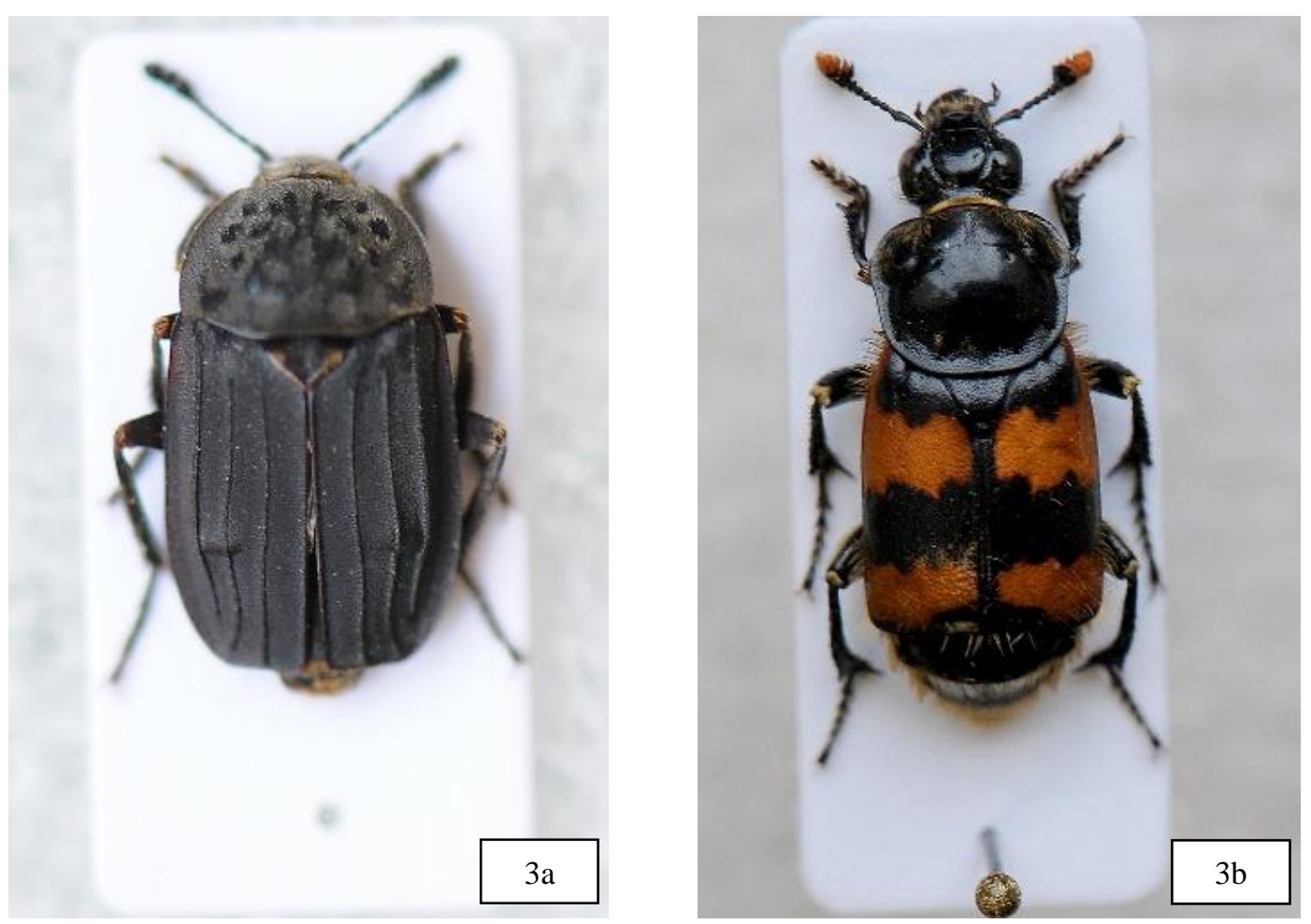

Figure 3. Most numerous Silphidae. 3a-representative of Silphinae - T. sinuatus; $3 b$ representative of Nicrophorinae - $N$. vespillo

In describing the assemblages of beetles, an important element is to analyze the dominance structure (Table 4). Among all the study sites, five dominant groups were only found in the field margin in Borek Stary in 2009 and in the field margin next to the 
cereal crop in Widna Góra. No dominant class was found at the other sites, except for the fodder beet crop. In turn, the highest number of subdominants was recorded in the mixed cereal crop. These were the following species: O. thoracicum, P. atrata atrata, $S$. carinata, S. obscura obscura, $N$. humator, and N. interruptus. Generally, the recedent and subrecedent classes were the most numerous groups as regards the species grouped in them.

The dendrogram of the species composition similarity of the study sites displayed significant differences (Fig. 4). Two main agglomerations that grouped the sites from the same localities were distinguished. Evidently, the field margins in Borek Stary distinguished themselves from the other study areas. The fodder beet crop and the field margin adjacent to it were the sites in the agriculturally used area in Widna Góra which were characterized by the greatest similarity.

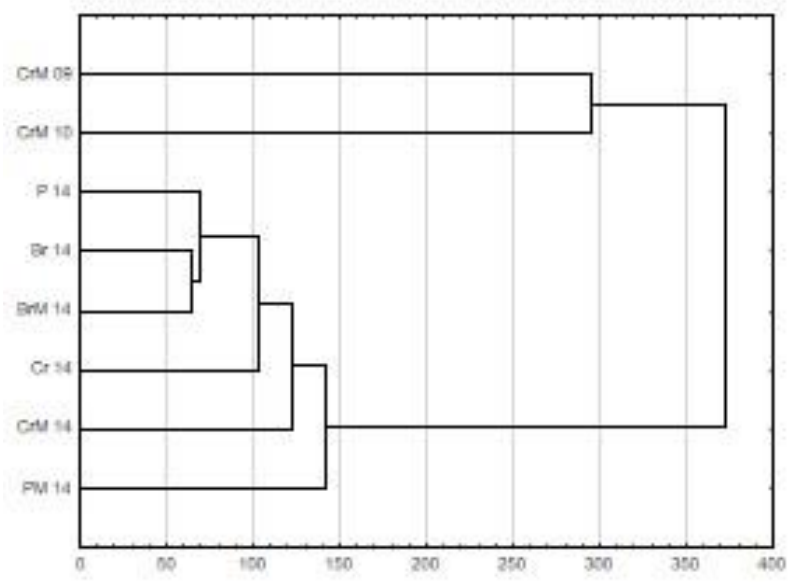

Figure 4. Dendrogram of similarity of Silphidae caught at the study sites. CrM-field margin in cereal crop, BrM-field margin in fodder beet crop, PM-field margin in potato crop, Cr-cereal crop, P-potato crop, Br-fodder beet crop, years: 09-2009, 10- 2010, 14- 2014

\section{Discussion}

In the case of studies directly focused on the family Silphidae, bait traps are usually used (Novák, 1961, 1962; Petruška, 1968; Kamińska, 1980; Růžička, 1994; Kočárek and Benko, 1997). Due to the trophic structure and reproductive behavior of carrion beetles, such methodology gives better results of catches (Coyle and Larsen, 1998; Kočárek, 2000; Brousseau et al., 2010). This can be confirmed by the catches in the potato crop. 9 Silphidae species, represented by 457 individuals, were recorded in Widna Góra. On the other hand, in a previous cross-sectional study of the Subcarpathian region which was conducted using unbaited traps, a significantly lower number of Silphidae was trapped, both in qualitative and quantitative terms (Konieczna et al., 2014).

In the potato crop (similarly to all the other sites), the eudominant species were $T$. sinuatus and $N$. vespillo. Another important species in the dominance structure was $S$. obscura obscura, which made up the subdominant class (no dominants were found). Juen et al. (2003) found the above-mentioned species to be present in organic potato crops, but with a different order of dominance, since $S$. obscura obscura proved to be the most numerous species. But $T$. sinuatus, whose number was 355 specimens in Widna Góra, showed a very low number (3 ex.) in the study by Juen et al. (2003). In 
total, the above cited authors recorded 4 species in the imaginal stage (104 ex.) and 5 species in the pre-imaginal stage ( 86 ex. +11 ex. Thanatophilus sp.) in the organic potato crop. Both in qualitative and quantitative terms, the results of the investigations carried out in Widna Góra were distinctly different from the results of Juen et al. (2003), which may be associated with the use of bait traps. A publication by Aleksandrowicz (2002), which relates to the effect of spraying with the insecticide Decis on beetle assemblies occurring in potato crops, draws similar conclusions. In this research, $S$. obscura obscura was also the most numerous representative of Silphidae. $N$. vespillo, in turn, which had the status of eudominant in Widna Góra, was classified as a subrecedent in the study by Aleksandrowicz (2002).

In the fodder beet crop site, the lowest number of species ( 8 taxa) was identified among all the sampling areas. The number of representatives of the genus Nicrophorus was also lowest. The following three taxa were observed: $N$. interruptus, $N$. vespillo, and N. vespilloides. Different results were obtained by Novák $(1961,1962)$ and Petruška (1968). Their research was carried out in Czechoslovakia and related to the genus Nicrophorus. Novák (1961) showed 8 species to be present in a fodder beet crop. In a subsequent study, 7 taxa were found (Novák, 1962; Petruška, 1968). Compared to the study conducted in Widna Gora, the three mentioned species were also found in the studies of the above-mentioned authors. Both in the above-mentioned publications and in the present study, the dominant species was $N$. vespillo.

A study on the impact of application of organic fertilizers on beneficial entomofauna in sugar beet crops was conducted by Porhajašová et al. (2015). The Silphidae was the third largest beetle family found in this study (5.23\% of the total assemblage), but it was dominated by Carabidae (63.86\%) and Staphylinidae (20.07\%). In this case, it can also be presumed that the absence of bait was one of the factors determining the catches of carrion beetles.

Among the crop fields studied, the site where the highest numbers of Staphylinidae beetles were found was the mixed cereal crop, where 673 individuals classified in 11 species had been trapped. As far as the number of taxa is concerned, Kamińska (1980) obtained different results. In wheat and barley growing fields, she demonstrated only 3 carrion beetle species (554 individuals). It is worth adding that, similarly to the study done in Widna Góra, in the research conducted by Kamińska (1980) the dominant species were $T$. sinuatus and $N$. vespillo. The same species were the most numerous group in terms of dominance in a study conducted by Tamutis et al. (2007). Their observations were focused on the occurrence of epigeic coleopterofauna in conventional and organic barley crops. This research revealed that, depending on the agricultural production system, the Silphidae catches were different. Under conventional cropping conditions, 6 carrion beetle species were found, represented by 660 individuals. In the organic crops, 5 species were found, but with a twice lower number of individuals (326). In a study carried out by Varvara and Zamfirensu (2009) in a wheat plantation, the trapped Silphidae accounted for $20.62 \%$ of the entire assembly of beetles caught, thus constituting the second largest family of this order. Shah et al. (2003), on the other hand, obtained completely different results for winter cereal crops. Only one species was recorded there $-N$. vespillo, represented by 6 individuals.

Monocotyledonous crops are characterized by a high and dense canopy, and mechanical agronomic treatments are limited to soil preparation before seeding and direct harvest. Such a habitat structure can create more favorable living conditions for beetles (even for temporary living). On the other hand, a lower number of individuals 
was found at the other crop sites (the potato crop and the fodder beet crop), which may indicate the unattractiveness of the habitat, due to both the nature of cropping (a low crop canopy, monoculture, the lack of floristic diversity, a lower probability of finding food) and the intensity of agronomic operations performed.

As a result of the catches conducted in the field margins, the highest numbers of beetles were shown in the field margin next to the mixed cereal crop in Borek Stary. Over the two-year study period in this area, a total of 2544 specimens representing 13 species were captured. The same number of identified taxa was determined in the field margin adjacent to the potato crop and in the field margin next to the mixed cereal crop in Widna Góra, but with a lower number of individuals.

Field margins that exhibit both floristic and structural diversity promote increased insect biodiversity (Thomas and Marshall, 1999). Field margins, field boundary strips or parts of arable fields excluded from agricultural production are biodiversity refuges, while predatory entomofauna inhabiting there may contribute to biological pest control (Fry, 1995; Wratten, 1998). In the field margins bordering the mixed cereal crop, the faunistic similarity was $100.0 \%$ (Borek Stary and Widna Góra). The high numbers of Silphidae trapped at these sites can be associated with the nature of the adjacent crops.

The publications of Růžička (1994) as well as of Kočárka and Benko (1997) can be mentioned among the few studies regarding the occurrence of carrion beetles in field margins. Růžička (1994) described open spaces excluded from agricultural use. His observations were carried out, among others, in a field margin overgrown with Urtica and Cirsium and bordering a maize crop as well as on an edge of a barley crop bordering a hornbeam (Carpinus) coppice. At these sites, a total of 13 species were found, out of which 11 species were common with the species captured in the field margin in Borek Stary as well as in the field margin adjacent to the potato crop and the field margin adjacent to the mixed cereal crop in Widna Góra. The study by Růžička (1994) demonstrated the presence of Aclypea opaca (1 ex.) and Dendroxena quadrimaculata (1 ex.), which did not occur in this study. On the other hand, in our study two species were recorded which Růžička (1994) did not confirm to occur. These were the following species: S. obscura obscura and $S$. carinata.

In a field margin separating a barley crop and a maize crop, in turn, Kočárek and Benko (1997) found the presence of 226 individuals from 10 species, out of which 9 occurred both in Borek Stary and in Widna Góra. In their study, the most frequently occurring species were T. sinuatus and $N$. vespillo.

\section{Conclusion}

When analyzing the qualitative and quantitative structure of the Silphidae caught in the field margins relative to the crop fields adjacent to them, a general trend was noticed towards the occurrence of a higher number of individuals and a lower number of species at the environmentally poorer sites (the crop fields). In the field margins bordering the crops, on the other hand, lower numbers of individuals were recorded, but a higher number of taxa identified. Such a distribution of beetles confirms Thienemann's biocenotic rule (1920), according to which the increased diversity of a habitat entails a decline in the total number of individuals. On the other hand, the proportion of recedents and subrecedents, that is, individuals that are few in number but which are important in the aspect of biodiversity preservation, increases. 
Acknowledgements. We would like to thank Tomasz Olbrycht, PhD Eng, from Department of Agroecology, Faculty of Biology and Agriculture, Rzeszów University, for help to prepare the pictures of Silphidae.

\section{REFERENCES}

[1] Agvin, S. S., Luff, M. L. (2010): Ground beetles (Coleoptera: Carabidae) as bioindicators of human impact. - Mun. Ent. Zool. 5(1): 209-215.

[2] Aleksandrowicz, O. (2002): Influence of Decis spraying on the community structure and species composition of beetles (Insecta: Coleoptera) on a potato field. - Baltic J. Coleopterol. 2(2): 145-153.

[3] Andersen, A. (1997): Denisities of overwintering carabids and staphylinidis (Col., Carabidae and Staphylinidae) in cereal and grass fields and their boundaries. - J. Appl. Entomol. 121: 77-80.

[4] Andersen, A., Hansen, Á. G., Rydland, N., Øyre, G. (1983): Carabidae and Staphylinidae (Col.) as predators of eggs of the turnip root fly Delia floralis Fallén (Diptera, Anthomyiidae) in cage experiments. - Z. Ang. Ent. 95: 499-506.

[5] Anderson, S., Peck. B. (1985): The Insects and Arachnids of Canada, Part 13: The Carrion Beetles of Canada and Alaska (Coleoptera: Silphidae and Agyrtidae). Agriculture Canada, Ottawa.

[6] Arus, L., Kikas, A., Luik, A. (2012): Carabidae as natural enemies of the raspberry beetle (Byturus tomentosus F.). - Agriculture 99(3): 327-332.

[7] Balog, A., Markó, V. (2006): Studies on rove beetles (Coleoptera: Staphylinidae) in Hungarian orchards ecosystems. - Journal of Fruit and Ornamental Plant Research 14(Suppl. 3): 149-159.

[8] Barabasz-Krasny, B. (2011): Vegetation differentiation and secondary succession on abandoned agricultural grand-areas in Przemyśl Foothills (South-Eastern Poland). - Wyd. IB im. W. Szafera PAN, Kraków (in Polish).

[9] Baronio, P. (1974): The insect enemies of gasteropodous mollusks. - Boll. Ist. Ent. Univ. Studi Bologna 32: 167-187 (in Italian).

[10] Beiroz, W., Zaú, A. S., Castro Jr., E. (2010): Impacts of road in the distribution of beetles in a fragment of Atlantic forest hill in Tijuca National Park, Rio de Janeiro, RJ. - RJ. Entomo Brasilis 3(3): 64-68 (in Portuguese).

[11] Bohac, J., Jedlicka, P., Frouz, J. (1999): Changes in communities of staphylinid beetles (Coleoptera, Staphylinidae) during secondary succession in abandoned fields. $-5^{\text {th }}$ Central European Workshop on Soil Zoology. Ceske Budejovice, 27-30 April, 1999, pp. $19-25$.

[12] Boone, R. D., Grigal, D. F., Sollins, P., Ahrens, R. J., Armstrong, D. E. (1999): Soil Sampling, Preparation, Archiving, and Quality Control. - In: Robertson, G. P., Coleman, D. C., Bledsoe, C. S., Sollins, P. (eds.) Standard Soil Methods for Long-Term Ecological Research. Oxford University Press, New York.

[13] Braun-Blanquet, J. (1964): Sociology of Plants. Basics of the Science of Vegetation. 3. Ed. - Springer Verlag, Wien-New York (in German).

[14] Brousseau, P. M., Cloutier, C., Hébert, C. (2010): Selected beetle assemblages captured in pitfall traps baited with deer dung or meat in balsam fir and sugar maple forests of Central Quebec. - Environmental Ecology 39: 1151-1158. DOI.org/10.1603/EN10045.

[15] Bukejs, A. (2009): Complex of carabid beetles (Coleoptera: Carabidae) of potato field agrocenosis in eastern Latvia. - Acta Zoologica Lituanica 19(3): 199-205.

[16] Bukejs, A., Balalaikins, M. (2008): Ground beetles (Coleoptera: Carabidae) of wheat agrocenosis in Latvia. - Acta Zoologica Lituanica 18(2): 134-138.

[17] Coleman, D. C., Hendrix, P. F. (2000): Invertebrates as Webmasters in Ecosystems. CABI Publishing, Wallingford. 
[18] Coyle, D. R., Larsen, K. J. (1998): Carrion beetles (Coleoptera: Silphidae) of Northeastern Iowa: a comparison of baits for sampling. - The Journal of the Iowa Academy of Science: JIAS 105(4): http://scholarworks.uni.edu/jias/vol105/iss4/6. 23.03.2017.

[19] Dekeirsschieter, J., Verheggen, F., Lognay, G., Haubruge, E. (2011): Large carrion beetles (Coleoptera, Silphidae) in Western Europe: a review. - Biotechnology, Agronomy, Society and Environment 15(3): 435-447.

[20] dos Santos Fernandes, F., da Silva Alves, S., Freitas Santos, H., Costa Rodrigues, W. (2011): Staphylinidae and Silphidae (Beetles) as Potencial Biomakers Families Of Environmental Quality. - Revista Eletrônica TECCEN, Vassouras 4(3): 17-32 (in Portuguese).

[21] Eyre, M. D., Luff, M. L., Atlihan, R., Leifert, C. (2012): Ground beetle species (Carabidae, Coleoptera) activity and richness in relation to crop type, fertility management and crop protection in a farm management comparison trial. - Annals of Applied Biology 2: 169-179.

[22] Fiera, C., Purice, D., Maican, S. (2013): The communities structure of invertebrate fauna from rape and alfalfa crops (Singureni, Giurgiu Conty, Romania). - Certecári Agronomice în Moldova XLVI 4(156): 65-74.

[23] Frank, T., Reichhart, B. (2004): Staphylinidae and Carabidae overwintering in wheat and sown wildflower areas of different age. - Bulletin of Entomological Research 94: 209217.

[24] Fry, G. (1995): Landscape Ecology of Insect Movement in Arable Ecosystems. - In: Glen, D. M., Greaves, M. P., Anderson, H. M. (eds.) Ecology and Integrated Farming System. John Wiley and Sons, Bristol.

[25] Ghahari, H., Anlaş, H., Sakenin, H., Ostovan, H., Tabari, M. (2009): A contribution to the rove beetles (Coleoptera: Staphylinoidea: Staphylinidae) of Iranian rice fields and surrounding grasslands. - Linzer Biol. Beitr. 41(2): 1959-1968.

[26] Górny, M., Grüm, L. (1981): Methods Using in Soil Zoology. - PWN, Warszawa, Poland (in Polish).

[27] Grynia, M., Kryszak, A. (1999): Comparison of floristic diversity of meadow communities occurring most often in the Bystrzyckie mountains and Karkonosze. PTPN, Pr. Kom. Nauk Rol. i Leśn. 87: 19-25 (in Polish).

[28] Heymons, R., von Lengerken, H. (1932): Studies on the life symptoms of the Silphini (Coleopt.). VIII. Ablattaria laevigata F. - Z. Morphol. Oekol. Tiere 24: 259-87 (in German).

[29] Holland, J. M., Luff, M. L. (2000): The effects of agricultural practices on Carabidae in temperate agroecosystems. - Integrated Pest Management Reviews 5: 109-129.

[30] Honěk, A., Jarošík, V. (2000): The role of crop density, seed and aphid presence in diversification of field communities of Carabidae (Coleoptera). - Eur. J. Entomol. 97: 517-525.

[31] Huruk, S. (2006): Comparison of structure of carabid (Coleoptera: Carabidae) communities of hay meadows and adjacent cultivated fields. - Wiad. entomol. 25 Supl. 1: 9-23 (in Polish).

[32] Jakubec, P., Růžička, J. (2012): Distribution of open landscape carrion beetles (Coleoptera: Silphidae) in selected lowlands of the Czech Republic. - Klapalekiana 48: 169-189 (in Czech).

[33] Juen, A., Steinbergen, K. H., Traugott, M. (2003): Seasonal change in species composition and size distribution of epigeic predators in a small field. - Entomol Gener 26(4): 259-275.

[34] Kamińska, D. (1989): Appearance of the silphids (Silphidae) on crop fields in the springsummer period. - Acta Univ. Nicolai Copernici, Biol. 33: 45-57 (in Polish). 
[35] Kočárek, P. (1997): Distribution of Silphidae and Leiodidae: Chlolevinae (Coleoptera) in Litovelské Pomoraví protected landscape area. - Zprávy Vlastivědného Muzea v Olomouci 275: 17-29 (in Czech).

[36] Kočárek, P. (2000): A pitfall trap for carrion ecology studies. - Biologia, Bratislava 55(5): 575-577.

[37] Kočárek, P., Benko, K. (1997): Occurrence and distribution of Silphidae in Hlučín region (Silesia, Czech Republic). - Cas. Slez. Muz. Opava (A) 46: 173-179 (in Czech).

[38] Konieczna, K., Krupa, B. (2013): Insects as a model to define ecosystem services. - Zesz. Nauk. PTIE i PTG Oddział w Rzeszowie 16: 45-52 (in Polish).

[39] Konieczna, K., Czerniakowski, Z., Olbrycht, T. (2014): Contribution to the knowledge of carrion beetles (Col., Silphidae) assemblages in potato cultures and forests in selected regions of south-eastern Poland. - EPISTEME 22(1): 173-184 (in Polish).

[40] Kostuch, R. (2000): Synthesis of national research and achievements in the grazing economy in the 20th century. - Zesz. Nauk. AR w Krakowie 368, Sesja Naukowa 73: 159-173 (in Polish).

[41] Kryszak, A., Kryszak, J., Grynia, M. (2006): Occurrence of Calamagrostis epigejos in grass communities in Wielkopolska. - Łąkarstwo w Polsce 9: 113-121 (in Polish).

[42] Lemic, D., Ĉaĉija, M., ViriĆ Gašparić, H., Drmić, Bažok, R., Pajaĉ Živković, I. (2017): The ground beetle (Coleoptera: Carabidae) community in an intensively managed agricultural landscape. - Applied Ecology and Environmental Research 15(4): 661-674.

[43] Linssen, E. F. (1959): Beetles of the British Isles. First Series Caraboidea -Diversicornia. The Wayside and Woodland Series. - F. Warne and Co., London and New York.

[44] Magurran, A. (2004): Measuring Biological Diversity. - Blackwell Publishing, Oxford.

[45] Marshall, E. J. P., Moonen, A. C. (2002): Field margins in northern Europe: their functions and interactions with agriculture. - Agric Ecosyst Environ 89: 5-21.

[46] McGeoch, M. (1998): The selection, testing and application of terrestrial insects as bioindicators. - Biological Reviews 73: 181-201.

[47] Mroczkowski, M. (1955): Carrion Beetles - Silphidae. Klucze do Oznaczania Owadów Polski. - PWN, Warszawa (in Polish).

[48] Nichols, E., Larsen, T., Spector, S., Davis, A. L., Escobar, F., Favila, M., Vulinec, K. (2007): Global dung beetle response to tropical forest modification and fragmentation: A quantitative literature review and meta-analysis. - Biological Conservation 137: 1-19.

[49] Novák, B. (1961): Seasonal occurrence of carrion beetles in field entomocenoses. - Acta Univ. Pal. Olomuc., Fac. Rer. Nat. 6: 45-114 (in Czech).

[50] Novák, B. (1962): Contribution to faunistic and ecology of the carrion beetles (Col. Silphidae). - Acta Univ. Pal. Olomuc., Fac. Rer. Nat. 11: 263-300 (in Czech).

[51] Nowiński, M. (1967): Polish Grass and Sedge Communities. - Państwowe Wydawnictwo Rolnicze i Leśne, Warszawa (in Polish).

[52] O'Rourke, M. E., Liebman, M., Rice, M. E. (2008): Ground beetle (Coleoptera: Carabidae) assemblages in conventional and diversified crop rotation systems. - Environ Entomol 37(1): 121-130.

[53] Otręba, A., Michalska-Hejduk, D. (2014): Invasive plant species in the Kampinos National Park and its surroundings. - Wyd. Kampinoski Park Narodowy, Izabelin (in Polish).

[54] Pawłowski, B. (1977): Composition and Construction of plant Communities and Methods of Their Examination. - In: Szafer, W., Zarzycki, K. (eds.) Systematyka polskich zbiorowisk roślinnych. PWN, Warszawa (in Polish).

[55] Petruška, F. (1968): The carrion-beetles as a component part of the insects fauna of the fields in the Uničov Plain (Col., Silphidae). - Acta Univ. Pal. Olomuc., Fac. Rec. Nat. 28: 159-187 (in Czech).

[56] Pielou, E. C. (1966): The measurement of diversity in different types of biological collections. - J. Theor. Biol. 13: 131-144. 
[57] Plate, H. P. (1951): The ecological relationships between arthropods and mollusks. Zeitschrift für Angewandte Entomologie 32: 406-432 (in German).

[58] Porhajašová, J., Noskovič, J., Rakovská, A., Babošová, M., Čeryová, T. (2015): Impact of application of organic fertilizers on biodiversity and spatial structure of families Coleoptera in southwestern part of the Slovak Republic. - Research Journal of Agricultural Science 47(1): 167-173.

[59] Rainio, J., Niemelä, J. (2003): Ground beetles (Coleoptera: Carabidae) as bioindicators. Biodiversity and Conservation 12: 487-506.

[60] Renkema, J. M., Cutler, G. C., Blanchard, D., Hammermeister, A. (2014): Using ground beetles (Coleoptera: Carabidae) to control slugs (Gastropoda: Pulmonata) in salad greens in the laboratory and greenhouse. - The Canadian Eentomologist 146(5): 567-578.

[61] Růžička, J. (1994): Seasonal activity and habitat associations of Silphidae and Leiodidae: Cholevinae (Coleoptera) in central Bohemia. - Acta Soc. Zool. Bohem. 58: 67-78.

[62] Schlechter, J. (2008): Beetle fauna found on carrion in three woodland sites in Luxembourg (Insecta, Coleoptera). - Bull. Soc. Nat. Luxemb. 109: 97-100.

[63] Schwerk, A., Dymitryszyn, I. (2017): Mowing intensity influences degree of changes in carabid beetles assemblages. - Applied Ecology and Environmental Research 15(4): 427440.

[64] Shah, P. A., Brooks, D. R., Asby, J. E., Perry, J. N., Woiwod, I. P. (2003): Diversity and abundance of the coleopteran fauna from organic and conventional system in southern England. - Agricultural and Fores Entomology 5: 51-60.

[65] Shannon, C. E., Weaver, W. (1949): The Mathematical Theory of Communication. - The University of Illinois Press, Urbana.

[66] Sikes, D. (2008): Carrion Beetles (Coleoptera: Silphidae). - In: Capinera, J. L. (ed.) Encyclopedia of Entomology. Vol. 1A-C. Springer, Berlin.

[67] Stanovský, J., Kočárek, P., Roháčová, M. (2005): Ground and carrion beetles (Coleoptera: Carabidae, Silphidae) of the Natural Monument Kamenec (Podbeskydský biogeographical region, Czech Republic). - Práce a Stud. Muz. Beskyd (Přír. Vědy) 15: 35-44 (in Czech).

[68] Stoate, C., Boatman, N. D., Borralho, R. J., Carvalho, C. R., de Snoo, G. R., Eden, P. (2001): Ecological impacts of arable intensification in Europe. - J Environ Manag 63: 337-365.

[69] Šustek, Z. (1981): Czechoslovak carrion beetles (Coleoptera, Silphidae). Reports of the Czechoslovak Entomological Society ACCA. - Klíče k určování hmyzu 2: 1-47 (in Czech).

[70] Tamutis, V., Monsevicius, V., Pekarskas, J. (2004): Ground and rove beetles (Coleoptera: Carabidae, Staphylinidae) in ecological and conventional winter wheat fields. - Baltic J. Coleopterol. 4(1): 31-40.

[71] Tamutis, V., Žiogas, A., Šaluchaitè, A., Kazlauskaitè, S., Amšiejus, A. (2007): Epigeic beetle (Coleoptera) communities in summer barley agrocenoses. - Baltic J. Coleopterol. 7(1): 83-98.

[72] Thienemann, A. (1920): The basics of biocenotics and Monard faunistic principles. Festschrift Zschokke Basel. 4: 1-14 (in German).

[73] Thomas, C. F. G., Marshall, E. J. P. (1999): Arthropod abundance and diversity in differently vegetated margins of arable fields. - Agric. Ecosyst. Environ. 72: 131-144.

[74] Tischler, W. (1955): Influence of Soil Types on the Epigeic Fauna of Agricultural Land. - In: Kevan, K. (ed.) Soil Zoology. Butterworths Scientific Publications, London, UK.

[75] Tokarska-Guzik, B., Dajdok, Z., Zając, M., Zając, A., Urbisz, A., Danielewicz, W., Hołdyński Cz. (2012): Alien Plants in Poland with Particular Reference to Invasive Species. - Generalna Dyrekcja Ochrony Środowiska, Warszawa (in Polish).

[76] Varvara, M., Zamfirescu, S. R. (2009): Numerical and percentage variation of some supraspecific taxa of some epigeic arthropods in the wheat crop. - Chirita, Iaşi County. 
Analele Științifice ale Universității „Al. I. Cuza” Iași, s. Biologie animală, Tom LV: 111 124.

[77] Wink, C., Guedes, J. V. C., Fagundes, C. K., Rovedder, A. P.(2005): Soilborne insects as indicators of environmental quality. - Revista de Ciências Agroveterinárias 4(1): 60-70 (in Portuguese).

[78] Wratten, S. D. (1988): The role of field boundaries as reservoirs of beneficial insects. Park, J. R. (ed.) Environmental Management in Agriculture: European Perspectives. Belhaven Press, London.

[79] Wysocki, C., Sikorski, P. (2014): Phytosociology used in landscape protection and shaping. - Wyd. SGGW, Warszawa (in Polish). 